\title{
UMBATRA
}

Indonesian Journal of Anthropology

Volume 5 (1) Juli 2020 || eISSN 2528-1569 | pISSN 2528-2115 || http://jurnal.unpad.ac.id/umbara

DOI : 10.24198/umbara.v5i1.28143

\section{Rumah Akses: Reconstructing Homes and Everyday Lives of the Newly Disabled Women after The 2006 Earthquake in Bantul, Yogyakarta}

\author{
Fina Itriyati \\ Departemen Sosiologi, FISIPOL, Universitas Gadjah Mada \\ itriyati.fina@ugm.ac.id
}

\begin{abstract}
The 2006 earthquake in Yogyakarta had already passed. However, the process of adaptation carried out by every individual is different. In this article, I disclose the experiences of women with disabilities in their adaptation to their new lives, especially in building accessible homes, negotiating with donors and positioning themselves and their roles new in the family and community. By employing ethnographic methods, I found that even though women with disabilities experience limited mobility, marginalisation and stigma as passive recipients of assistance, they still try to build agencies while overcoming challenges during the process of housing reconstruction. To realise the accessible housing, they utilise their identity as persons with disabilities to complete their access houses, redefine the concept of an ideal home according to Javanese culture and maintain their position as a pillar of the household to maintain their bargaining power in the household. Through sabar (patience), nrimo (acceptance) and ikhlas (sincerity) women with new disabilities have exercised their agency not only in the process of housing reconstruction but also in the long-term journey of recovery after the disaster.
\end{abstract}

Keywords: the newly disabled women, marginalisation, accessible housing, agency

\begin{abstract}
Abstrak
Gempa bumi yang terjadi di Yogyakarta pada tahun 2006 sudah berlalu. Di Kabupatan Bantul, salah satu area yang paling terdampak dari gempa tersebut sudah tidak terlihat bekas kerusakan. Namun, proses adaptasi setelah bencana ternyata harus terus-menerus dilakukan oleh penyandang disabilitas baru yang mengalami disabilitas permanen akibat gempa bumi tersebut. Pengalaman penyandang disabilitas dalam merekonstruksi kehidupan mereka berbeda dengan pengalaman anggota masyarakat lainnya sehingga dalam artikel ini, penulis secara khusus mengelaborasi pengalaman perempuan penyandang disabilitas baru dalam adaptasinya dengan kehidupannya yang baru terutama dalam membangun rumah yang aksesibel, bernegosiasi dengan pihak donor, dan memposisikan diri dan peran mereka yang baru dalam keluarga dan masyarakat. Dengan menggunakan metode etnografi, peneliti menemukan bahwa meskipun perempuan dengan disabilitas mengalami keterbatasan mobilitas, termarginalisasi dan mendapatkan stigma sebagai penerima bantuan yang pasif dan tidak berkontribusi dalam gotong royong pembangunan kembali desa
\end{abstract}


mereka, mereka tetap berusaha membangun agensi sekaligus mengatasi tantangan-tantangan yang muncul dalam proses rekonstruksi paska bencana. Dalam konteks pembangunan rumah aksesibel, mereka menggunakan identitasnya sebagai penyandang disabilitas untuk melengkapi rumah aksesnya, memaknai ulang konsep rumah ideal menurut budaya Jawa dan mempertahankan kekuatan mereka sebagai pilar rumah tangga sebagai upaya untuk mempertahankan daya tawar mereka dalam rumah tangga. Transformasi mereka sebagai perempuan dengan disabilitas tidak serta membuat mereka menjadi individu yang pasif. Melalui sabar, nrimo, dan ikhlas, perempuan penyandang disabilitas baru semakin memperkuat agensi mereka tidak hanya dalam proses rekonstruksi rumah tetapi juga dalam perjalanan jangka panjang penyembuhan kehidupan mereka paska bencana.

Kata kunci: perempuan dengan disabilitas baru, marginalisasi, rumah akses, agensi

\section{Introduction}

"There is not a time limit on rebuilding lives. Some people are recovering quicker, and some are still left behind." (McManus, 2007)

For residents in Bantul and Yogyakarta who experienced the 2006 earthquake, the period of reconstruction after the disaster emergency was the most critical stage for rebuilding their lives. However, while the impact of the earthquake for affected people was prolonged and their situation remained largely invisible to the wider community the dominant measurement for successful post-disaster development was the completion of the respective emergency, rehabilitation, and physical reconstruction stages (Pathranarakul and Moe, 2006). In the reconstruction phase, the existence of public facilities, infrastructure, roads, housing and access to employment and services became vital measures for decision makers to assess the progress of the disaster recovery. In the case of the Bantul earthquake, the remarkably rapid reconstruction of housing and infrastructure achieved domestic and international renown and the spirit of gotong-royong (mutual help) became an important lesson for disaster research and management in many places (Kresnomukti et al, 2009).

During the process of recovery and reconstruction, the slogan 'Bantul Bangkit' (Bantul Awakens) inspired survivors to carry out gotong royong (mutual help) to rebuild their lives and to reconstruct their dwellings, infrastructure, and neighbourhood in kampongs. 'Bantul
Bangkit' not only referred to awakening in the context of reconstruction but, in reality, people have used this notion of awakening to revitalise their lives. The slogan Bantul Bangkit was manifested through the participation of affected communities and people from neighbouring cities and districts to build their houses. In Mbak Ami's kampong, a group of mothers worked together to raise aid through their family networks, compiling and managing the donations and charity under the management of the village (padukuhan), the neighbourhood (rukun tetangga) and the ten houses grouping meeting (dasawisma).

The active participation of villagers from many different groups built social solidarity, creating a sense of 'we-ness' that impacted group boundaries and belonging (Drury, et al 2016; Tumer, 1981). The participation of survivors in the reconstruction of houses also positively affected their attitudes towards the newly built houses (Kamani-Fard, et al., 2012).

In the reconstruction phase, NGOs, the government and local people viewed the house as symbolising a 'better life', indicating the success of the reconstruction process and the enhancement of survivors' well being after the disaster. Samuels (2012) discusses how newly built homes have become one of the parameters of reconstruction success for NGOs and government, since a house provides material evidence for expenditure, enabling agencies to report to donors. However, Jauhola (2010) argues that disaster reconstruction efforts are 
not just technical; rather, they take place in particular social, political and economic environments, that are neither simplistic nor linear. Jauhola asserts that the disaster reconstruction process revealed a diverse range of human experience when people were exposed to the same degree of social inequality and suffering. It also revealed pre-disaster human vulnerabilities. Survivors thus experience the process of disaster reconstruction in diverse ways.

\section{Literature Review}

The disaster and disability experiences of the newly disabled people were not included in the main narrative of the 2006 earthquake recovery. Their experiences have never been written in the reports because they are mostly displayed as recipients of social assistance and aid. However, their narrative is buried in the glorification of the successful disaster management in Bantul. They were also invisible in the dominant discourse that focused on the Javanese people's ability to restore their harmonious life in the kampongs. My research is crucial because so far in the disaster discourse, the newly disabled people are represented as vulnerable groups who lacked agency and needed total intervention from persons without disabilities.

In Bantul, the program was overwhelming. The abundance of the physical construction of houses and infrastructure became the evidence of the celebration of BBB in the affected areas. Although the Building Back Better became a triumph in disaster recovery, there was a lot of criticism that the implementation of the program failed to meet the community's need to rebuild their lives for the better.

Interventions in Building Back Better are also felt to be incompatible with people's needs and culture. For example, in the study of post-disaster reconstruction after the 2005 Kashmir earthquake, the local community found difficulty in constructing their homes because the lack of technical assistance from the government neglected the needs of the local people.
The construction of houses that did not meet the needs and preferences of the local people left a substantial number of agency built houses unoccupied (Arlikatti et al., 2018; Halvorson and Hamilton, 2007). Also, the design of the function of new homes went ahead without consultation with homeowners and failed to satisfy their respective cultures.

In Aceh, the community responded to their post-tsunami houses by making some adjustments because the top-down housing program did not recognise them as active subjects but only beneficiaries that must receive and be thankful for their new homes. As a result of the size, design, typology, and location that did not fit with their livelihood and needs, the local people made modifications to their new houses. They enlarged the living room, merged the kitchen and added the veranda to fulfill their socio-cultural needs (Rahmayati, 2016). Based on these cases, I argue that the standardisation of disaster relief, including the housing aid, resulted in dissatisfaction within the community and inefficiency of the programs. Even more so for the people with disabilities, the standard housing did not fit their needs for a different way of life and made more difficult their survival.

\section{Method}

My informants were all recipients of an accessible house. To understand the dynamics of my informants' lives more deeply, I selected 12 informants whose activities I rigorously followed. I also interacted with their significant others in organisations, kampong meetings and three-wheeled motorcycle (sespan) rally. To supplement the data, I visited kampong leaders and neighbours. I undertook formal interviews with government officials, NGO activists, non-newly disabled people, donor representatives, general residents of Bantul and academics. The relationships of newly disabled women with their families, neighbours and other newly and non-newly disabled people were mapped during participant observation. While engaged in participant observation, I also collected secondary data. Using the research methodology of partici- 
pant observation, I commenced fieldwork in mid-January 2015 and finished on December in the same year.

\section{Results and Discussion}

\section{The Process of Reconstructing the Rumah Akses (Accessible House)}

According to UNISDR/United Nations International Strategy for Disaster Reduction (2009), 'disaster' refers to a severe disruption of the functioning of a community or a society involving widespread human, material, economic or environmental losses and impacts that exceed the ability of the affected population or society to cope by using its resources. The definition has become the justification for agencies to intervene in the lives of local people for the purposes of recovery, in order to return them to normalcy and improve their living conditions (Jauhola, 2015).

The Bantul housing reconstruction program has also been acknowledged as a lesson learnt for other post-disaster programs because of the synergy between multiple stakeholders and strengthening of local capacity through constructing an earthquake-resistant house (Marcillia and Ohno, 2012; Pribadi, et al., 2014; Rini, et al., 2016). In contrast, the accessible housing developed for disabled survivors was characterised by particular processes of intervention by donors, in which there was a lack of inclusion of the newly disabled in negotiating the size and design of the house. One of the newly disabled disclosed that the guidelines for the accessible housing reconstruction were fixed and the instructions were detailed. Therefore, the guidelines were not flexible to fit the different needs of the newly disabled women for bigger space and mobility facilities. The NGO staff and builders strictly followed the manual in order to simplify their reporting processes and accountability. The process of accessible housing reconstruction also neglected the potential of the community to participate in house building and created segregation of non-disabled and disabled families. The physical design of the house disregarded the need for the newly disabled people to interact with their community, effectively distancing those disabled people from their neighbourhood.

The development of accessible housing was executed entirely by NGOs carrying out short-term adjusted housing programs for handicapped people. The NGO involved in the process of reconstruction of houses for the disabled, the International Organization for Migration (IOM), donated accessible housing (rumah akses) for the newly disabled people who needed mobility assistance in their daily lives. Most of the beneficiaries were newly disabled wheelchair users. Alongside IOM, several other International NGOs also donated accessible housing to disabled survivors including Yayasan Umat (YU), Java Reconstruction Fund (JRF), Arsenova and YAKKUM.

Although IOM refers to accessible housing as 'adjustable housing', in this article, I use the term rumah akses, translated as 'accessible house' - the term used by informants in this research. The elaboration of the process of housing reconstruction together with the adaptation experiences of those living in the newly built house, and the relationship of the newly disabled women with their family and their interaction with NGO staff and neighbours, reveal the meaning of a new 'home' and its relationship to residents' sense of new self and identity.

\section{The Materiality of the Accessible House}

The sticker attached to Mbak Yanti's house marks the house, called an 'adjusted house', as part of an assistance program dedicated to disabled earthquake survivors. The housing program, which was funded by IOM in collaboration with the Netherlands Red Cross, provided physiotherapy and psychosocial support for the newly disabled people. The IOM built 80 permanent steel house frames designed for people enduring complete or partial paralysis and using a wheelchair for mobility (International Organization for Migration, 2007). Houses for disabled survivors carried certain design features such as large entrance doors, an accessible threshold at the entrance, and a 
toilet within a bathroom enabling wheelchair users to transfer from and into wheelchairs.

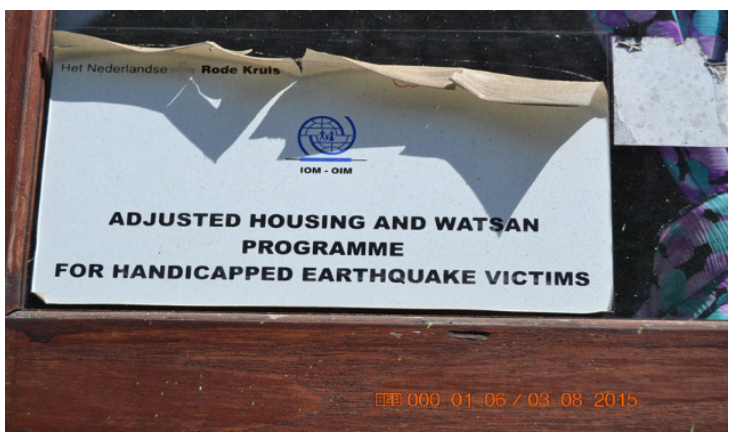

Figure 1. Sticker from IOM marks house donation to a newly disabled person's family, August 2015

The notion of accessibility has evolved since its origin in Western society in the 1950s. In contemporary terms it refers to efforts to enhance individuals' participation in the process of democracy and development and support individuals' contribution in all aspects of life in a democratic society (Persson, et al., 2015). Human rights discourse on accessibility views that people with a disability should have access, on an equal basis with non-disabled others, to the physical environment, transportation, information and communications (including information and communication technologies and systems), and other facilities and services available to the public in both urban and rural areas. 'Accessible housing' aims to support The Convention on the Rights of Persons with Disabilities (UNCRPD) to shift public attitudes towards people with disabilities. They should be seen as active subjects with the right to decide for themselves and to participate as members of society (Persson, et al., 2015). In the case of adjustable housing built by IOM after the earthquake, the accessible house programs emphasised allowing disabled people to perform their daily activities independently.

\section{Passive Recipients of the Accessible House}

The disabled people were automatically granted housing and were not required to participate in a process such as providing builders or contributing ideas. The newly disabled people and their families were only required to provide land to receive the grant. One of my informants, Mbak Eny (35), told me that she was not able to intervene in the accessible housing construction process because NGO staff, both from YAKKUM and IOM, had already set the design, size, and timetable and hired the construction workers.

In the post-disaster programs in Yogyakarta, it was humanitarian intervention agencies through the accessible housing programs that organised the governance of adversity. According to Fassin (2007), humanitarian programs have become a mode of Western intervention to influence policy in decision making related to managing catastrophes such as armed conflict and natural disasters and consequences of epidemics, famine, physical injury and emotional trauma. Through focusing on the legitimacy of assistance in the case of misfortune, injustice, suffering in times of emergency, starvation and war, humanitarian programs can influence the discourse in managing the disadvantaged population (Fassin, 2013). Through the grant of the accessible house, the newly disabled people became categorised as specific beneficiaries needing NGO assistance to adapt to their new lives as wheelchair users and practise their everyday lives in their accessible houses. They were excluded from participation in wider community recovery and seen as not qualified to engage in the programs developed by the government and the mainstream NGOs. The newly disabled people thus became 'bare life' (Agamben, 1998), rather than persons who had the right to be included alongside other survivors.

The depiction of them as living a 'bare life' is suggestive of the power of the NGO intervention over the lives of newly disabled people through programs that promised protection, dignity and guidance to return to a 'normal' life. The 'bare life', coined by Agamben (1998), refers to a form of life devoid of political voice; resulting in the lives of the disabled becoming the object of governance. The sovereign power that controls the subjects has the authority to decide whether certain forms of life are, indeed, worthy of life and worthy of becoming the object of intervention and research - but without the right to give advice to the policy or to know the results of the exam- 
ination upon their life (Agamben, 1998; Brasset and Vaughan-Williams, 2012; Meekosha and Soldatic, 2011; Phillips, 2009).

In the case of the post-earthquake intervention in Yogyakarta, the NGOs differentiated and categorised disabled and non-disabled survivors in order to determine the groups eligible for their assistance and empowerment programs. The newly disabled people, portrayed as vulnerable, passive and injured, thus became the object of discourse - pertaining to disability mainstreaming, independence and equality - that subjected them to protection and intervention from Western-origin aid agencies and their skilled, professional aid workers (Gill and Schlund-Vials, 2016; Kim, 2016). The segregation of programs for disabled and non-disabled people in times of post-disaster, combined with the universalisation of the disability experience, resulted in a gap in the needs of the disabled, rendering them vulnerable to alienation, and social and economic marginalisation (Ghai, 2002; Meekosha, 2011; Meekosha and Soldatic, 2011).

I argue that several aspects generated passivity and segregation in both disabled and non-disabled aid recipients of post-disaster programs in Yogyakarta. First, at the time of the disaster, social inclusion were not yet mainstreamed in disaster management. Secondly, the significant number of earthquake survivors who became disabled was unprecedented in Indonesia and neither disability-based NGOs nor other development NGOs had experience in managing such a caseload. Thirdly, disability-based NGOs who worked exclusively with the disabled effectively excluded the disabled from their community, dividing them on the basis of separate programs. As a consequence, many needs of the disabled people were not satisfied because not all mainstream programs were offered by the disability-based NGOs. Further, this separation also hampered disabled people's desire and need for more extensive networks. The minimal link between disability based-NGOs and other development NGOs produced segmentation and long-term segregation in the lives of disabled people and their communities. Finally, the disability-based NGOs internalised stereotypes pertaining to the disabled person, treating the newly disabled through a universal approach even though each person possessed a different life trajectory and character.

In the programs for housing relief, the NGOs treated the newly disabled people as passive subjects in need of help and assistance because they had been categorised as survivors in need of long-term professional intervention from outsiders. This is demonstrated in the actions of NGOs and donors in offering housing for the disabled without consulting with or seeking the active participation of either the disabled or their families in constructing the building. The absence of such a consultative process reduced their capacity to understand the requirements in creating a safe house for the newly disabled. The newly disabled women were unable to negotiate their need for spacious mobility because the donor had pre-determined the size, procedure and implementation of the house building process so that the recipients would each receive the same type of house. This allowed the donor to estimate and project the dollar cost for building each unit and the number of recipients to be targeted. Mbak Yanti, a 34-year-old newly disabled mother, described the NGOs' total assistance by underlining the ease with which she obtained her house. By simply declaring her agreement with the staff who offered the aid, she became the recipient of housing relief. She recounted the procedure for the reconstruction of her house:

"The process of making my house was different. It did not follow the same procedures as other survivors because, as a wheelchair user, I was considered a 'sick' person. While the other survivors participated in their house making, we disabled persons were just passive. The general survivors received community group [pokmas/kelompok masyarakat] funds from the government to build their houses, while we acquired the house 
from IOM-one of the international NGOs that delivered assistance to the disabled survivors. The process was just simple. IOM and Yakkum listed us, came, and asked whether we agreed to receive a house from the donors. The physiotherapist who often treated me asked me whether I needed an accessible house or not. 'Yes, of course', I replied. Who could reject aid? It is good fortune [reje$k i]$. My lost house that was made of brick collapsed completely when the earthquake occurred. Therefore, once I agreed to receive the funds, the IOM came and constructed the house for me." (Interview with Mbak Yanti, 2015)

Even though the newly disabled women were seen as passive beneficiaries who automatically received assistance from aid providers, the women themselves did not perceive that support as carrying stigma. Instead, they understood the support as a form of (other people's) attention that was inappropriate to reject. For them, the act of accepting aid reciprocated people's kindness in their lives. As Javanese women, they also viewed assistance as blessings that accompanied tragedy. On the other side, the labelling of the newly disabled as those most affected by disaster justified the donor programs as accountable — even though the recipients may have already received abundant aid from other organisations. $\mathrm{Bu}$ Tari (42) explained that JRF and other NGOs were involved in completing the construction of her new house. YAKKUM and Arsenova installed such infrastructure as toilets, wells, water towers, water faucets and water pumps. Habitat for Humanity also enabled accessibility by providing building materials such as cement, sand, and wood, although Bu Tari was required to contribute to the costs of engaging construction workers. Assistance was also granted by YAKKUM to build a wash basin and kitchen. This situation created a clear distinction between disabled and non-disabled survivors because the NGOs involved in the process of housing reconstruction were dif- ferent, and the types of assistance were also distinct. Bu Tari reflected on her experience of accessing support from various organisations:
"After four months living in the YAKKUM rehabilitation centre, I returned home. I only saw a ruined house. I lived in the shelter until I was able to access a bamboo hut from Partai Amanat Nasional [PAN, Na- tional Mandate Party]. At that time, many political parties competed to help the survivors to recover from the effects of the disaster, especially for those families who had suffered most. Therefore, it was quite easy to access a hut or temporary shelter from many sources. While we got help directly from various organisations, the other villagers received support that was distributed centrally by the village." (Interview with Bu Tari, 2015)

\section{Discovering Their Agency - The Transforma- tion of the Disabled}

Even though the donors treated them as passive victims who needed total assistance, as time went by $\mathrm{Bu}$ Tari and her family came to understand her disabled condition as privileged, enabling greater levels of bantuan (aid) from donors. They assertively looked for sources of aid and applied to become beneficiaries. As a result Bu Tari was able to modify and maximise the assistance that she received from outsiders. Initially she received an accessible house from YAKKUM and Habitat for Humanity. Then her husband (Pak Arjo, 49) utilised his status as an ordinary villager to obtain assistance from JRF, even though $\mathrm{Bu}$ Tari had already obtained a house from the disability-based NGOs. As a consequence, $\mathrm{Bu}$ Tari and Pak Arjo were able to expand their home by accessing another source of aid. They were thus able to extend their house and fit it with a washbasin and accessible toilet and sink, and enable access from the backyard. Bu Tari received support from JRF, YAKKUM, Arsenova and Habitat for Humanity to make her home complete.

The stereotype deployed by NGOs of the 
newly disabled, and the implementation of the aid by disregarding their voice and their participation in the process of housing reconstruction did not therefore become a crucial issue for all the newly disabled. Rather than complaining about the process, by accepting their condition as beneficiaries they developed a sense of agency. Mbak Sri, another informant, used the legitimacy of her disabled state to actively seek aid for her family. While Mbak Yanti chose to receive the house to reduce her dependency on her mother. Rather than feeling a certain weakness as the recipient of an accessible house, she cultivated a positive sense of being blessed in receiving her house. The construction of accessible toilet and accessible interior of the house helped Mbak Yanti perform household activities and fulfil her motherhood role. The comparatively passive character of the non-newly disabled people who were oppressed and marginalised for a long time did not occur in the case of the newly disabled people because of the pre-existing capacities of these individuals. It was, therefore, problematic when their trajectory and abilities of the past were ignored. To respond to that, the newly disabled women found ways to acquire their voice.

\section{Disempowerment and Empowerment in Home Making}

While a 'house' is widely understood as a physical or concrete building in which someone lives, a 'home' has a more abstract meaning as it has been seen as a socio-spatial entity, a psycho-spatial entity and an emotional place (Easthope, 2004). It is not only a place but also a living space that enables ideas and interactions (Young, 2005). The process of building accessible housing involved not only outsiders and external assistance but also communication and negotiation among family members, especially in the decision-making process. In the following discussion, I will elaborate the experiences some newly disabled women had of consultation with their family regarding decision-making, design, and meaning-making pertaining to the newly built house.

\section{Disempowerment in the Family}

In addition to NGOs encouraging newly dis- abled women's passivity in the process of constructing accessible housing, these women also encountered lack of inclusion in their family's decision-making with respect to building their house. While ordinarily these women were independent and autonomous as a result of the Javanese bilateral and matrifocal system, as stated by Blumberg (1984), in the emergency and recovery situation after the earthquake, several of my informants lost their voice in the process of consultancy with NGOs. Rather than being directly involved, they were represented by family members in communication with the NGOs as these newly disabled wives, sisters or mothers were considered sick people who needed the family's protection and as lacking the necessary assertiveness to make decisions. Even though for the Javanese, homemaking is a crucial matter that requires family involvement at every stage of the process, in fact, in the process of house building the newly disabled women seemed overtaken by other family members.

The process of decision-making during the building of these houses reveals the dynamics of relationships between the newly disabled women and their family members. In Mbak Yanti's case, as she was a single mother with a son, her older brother took full responsibility for all decisions regarding Mbak Yanti's process of recovery. He represented Mbak Yanti as their father was absent. Even though Mbak Yanti was the survivor entitled to a house donation from IOM, her brother made all the decisions about where the house would be built and acted as the point of contact for the builders. Mbak Yanti's brother also acted as her representative in communication with $\mathrm{NGO}$ staff regarding the house construction and supervised the process. Mbak Yanti described the decision-making process that took place during the rebuilding of her house:

\footnotetext{
"My brother made all the decisions related to the housing reconstruction without realising that I could not maximally benefit from the newly formed house and its facilities. He asked the builders to locate the kitchen and
} 
toilet at the very rear of my house. Consequently, I could not cook for myself. His position as oldest brother authorised him to manage the inherited land from my father. To show his responsibility, he also designed the layout of my accessible house. My brother placed my room and my living room at the front part of the house as he assumed that I was now a sick person needing quick access to the road and neighbourhood. He considered my needs to engage with my community even though I only tended to chat briefly with my next-door neighbours. That is [the limit of] what he knows about accessibility." (Interview with Mbak Yanti, 2016)

$\mathrm{Bu}$ Tari also experienced marginalisation in decision-making as a result of the stereotype of being a vulnerable woman. In the process of constructing the accessible house, Bu Tari's husband dominated communication with donors. He readily obtained aid because he could justify that his disabled wife needed priority access to assistance. He chose the location for the house, communicated with NGO staff and received the monthly direct cash payment from the government without surrendering it to $\mathrm{Bu}$ Tari. Men acting as decision makers in this way eclipsed the historically equal position of women in family decision-making. Even though $\mathrm{Bu}$ Tari realised that she had the right to decide the location of the house, she lost her voice in this process because her husband, as household head, had represented her as the beneficiary in discussions with NGO staff regarding the reconstruction of the house. The domination of men in the process of the physical construction of the house was also influenced by Javanese understandings that it is the role of men to handle the process of house construction, while women contribute more to the interior design, home decor and selection of furniture and equipment inside the house.

The double disadvantage experienced as non-household head and as a newly disabled person who had lost her mobility hindered $\mathrm{Bu}$ Tari's involvement in communication with NGO staff. Enarson (1999) advocates gender awareness when reconstruction occurs so that women's needs are met and their autonomy is improved in the post-disaster setting is thus pertinent to the Yogyakarta recovery. Mbak Yanti's and Bu Tari's experiences of marginalisation in decision making during the process of housing reconstruction is common among women in post-disaster settings; they are seen as a having a primary role as caregivers for their family rather than being involved in the process of reconstruction which is considered as a male domain in the society (Enarson, 1998). In the context of Yogyakarta, newly disabled women were subject to double marginalisation - as reflected in the cases of Mbak Yanti and $\mathrm{Bu}$ Tari-because they were seen as having no active role in the process of recovery and see as burdensome for their family.

\section{Empowerment Through Nrimo and Agency}

Understanding their position and the dynamics of relationships in the family, some newly disabled women used similar tactics to cope with their disadvantage. Mbak Yanti considered that the most appropriate behaviour in a time of crisis was to be nrimo (accepting) of older people's advice as, during her life, Mbak Yanti's mother had always educated her to respect older people, especially parents and older brothers. In her case, her oldest brother had the central authority to manage the family because their father lived with his other wife. Therefore, being nrimo of her brother's arrangement regarding the housing reconstruction demonstrated her respect for the elders in her family, reflecting Geertz's (1961) observation that in the Javanese family, people are taught to respect older people to preserve the norm of rukun (social harmony) and to avoid conflict in the family and community.

However, despite the circumstances that hindered Mbak Yanti's autonomy in decision making, she discovered ways to be patient (sabar) and to be grateful (bersyukur) regard- 
less of what happened-reflecting what her mother, Bu Tini (62), had always told her:

"Urip ki piye carane nrimo kersane Gusti Allah, bhen ora dadi memolo lan aja kuwalat karo wong tuwo." [Life is about accepting God in our lives in order to prevent bad luck. Moreover, do not reject the parents' command.] (Interview with $\mathrm{Bu}$ Tini, 2015)

$\mathrm{Bu}$ Tari also accepted that she could not actively engage in or control the process of house making as a result of her acute injury at that time. As she did not have a sibling and depended on her husband's family during her recovery, she followed their decisions regarding the distribution of assistance within the extended family. Her brother-in-law also assumed a significant role in the process of allocation of the resources that they received from many sources. Bu Tari thought that whatever the situation of her relationship with her own husband, she still needed her husband's family to take care of her during the process of her recovery. She also considered her young daughter's well-being under the supervision of her mother-in-law. In sum, she felt that she and her children needed an extended family to help them continue their lives into the future, and was aware of her subordinate position in relation to her husband and his family.

It can be said that in submitting to a situation that they could not change at the time both Mbak Yanti and Bu Tari were exercising their agency. Rather than seeing their extended family as burdensome or challenging their own interests, they viewed their extended family as a means for assisting their future independence. In the context of Bu Tari, her compliance in being used as a means to gain more aid formed part of her negotiation with her husband's family. Mbak Yanti and Bu Tari's tactics of manipulating aid and cultivating a sabar (patient) and nrimo (accepting) attitude constitute the exercise of agency. In spite of her husband's dominance of her bantuan (aid) and regular cash transfer received from the government and NGOs, Bu Tari did not perceive this as a loss of control. She practised being ikhlas (sincere) and sabar (patient) out of respect for her late mother who had arranged her marriage to Pak Arjo. The sincerity (keikhlasan) and patience (kesabaran) cultivated by $\mathrm{Bu}$ Tari did not mean that she was passive or surrendered. She believed that her persistent patience and sincerity, even though difficult, would benefit her through a 'good return' at the end-if not rewarded in this world, then she would be rewarded in the afterlife.

She practised ikhlas but insisted on arranging to design more accessible rooms that allows her to enter all places in her house. She believed that time speaks for itself and every problem expires in the face of the solution that emerges. Bu Tari's practice of sabar can be linked-to confidence in God in the face of hardship (Jouili, 2007). It gave her a sense of closeness to God and even a moral status as a pious woman (Mahmood, 2011; Qureshi, 2013) and perempuan kuat dan tabah (a strong and tough woman). But, at the same time, Bu Tari calculated the risk of remaining in a violent relationship with her husband. $S a$ bar for her meant waiting and enduring rough times, being brave in facing reality and being aware of the situation in case she needed to seek safety elsewhere. As she still needed help from her husband's family to take care of her and her children, she waited for the right time to leave her husband, engaging with a disability-based NGO that provided crisis assistance for disabled women and their children who were experiencing domestic violence and abuse. In case something happened, and she needed to save herself and her children, she knew where to go.

Mbak Yanti particularly emphasised the importance of nrimo. As she respected her brother and her mother, she accepted their decisions for her. In the period following the earthquake she realised that she needed much help from her family. I observed in Mbak Yanti's actions not passive acceptance but her embrace and acceptance of the situation (nrimo lelakon), and a readiness to endure and standby for 
the next challenge. I did not sense nrimo as passive acceptance, but as the first response to an unchangeable situation. She did not lose control of a situation but conserved her energy to face the consequences of being a disabled person. Nrimo in this case refers to acceptance with an active intention to move on to the new chapter of life; without the actions associated with nrimo (accepting), she could not grow and progress towards this new life. Mbak Yanti practised nrimo first, making it easier for her to endure the challenges. The practice of nrimo needs to be understood in reference to the concepts of lahir (outward) and batin (inward) aspects of life for the Javanese (Mulder, 1983). Nrimo does not denote a passive activity; it requires active olah rasa (training of the inner feeling) to guide the performance of lahir to better reflect the state of the batin inner being. Both Mbak Yanti and Bu Tari required the capacity and strength to pursue their own life goals.

The case of these newly disabled women recalls Saba Mahmood's study of the women's piety movement in Egypt (2011). Instead of seeing agency in choice and freedom to make decisions based on liberal Western values, Mahmood offers a different way to view women's agency under circumstances of Islamic patriarchy in Egypt. She reconceptualises the notion of agency, as not simply a synonym for resistance to social norms but as a modality of action. Agency refers to women's inherent capacity and power, as shown by the women's mosque movement, that does not require overt resistance to Islamic cultural hegemony and patriarchy. Instead, they maintain their religiosity by cultivating modesty and shyness to strengthen their piety and patience. They do not see piety and patience as Islamic patriarchal values imposed on them, as reflected in a liberal feminist point of view. Rather, they see piety and patience as good deeds and standards of morality that need to be pursued by both Muslim males and females - and such practices need effort. In the case of these newly disabled women, they did not confront their extended families or the NGOs, or condemn their life segregated from their neighbours, but practised sabar (patience) in managing their emotions. Step by step they attempted to change their situation as sabar does not mean accepting a situation that might be negotiated. As an Islamic principle, sabar also implies endurance and perseverance and great strength because a person still exercises choice in the situation; this is referred to as qodariyah (view of fate) (Mahmood, 2011).

Also, instead of being shy about their status as newly disabled women, some embraced their status as disabled persons to obtain assistance from outsiders and perceived themselves as legitimate beneficiaries. The strategy of these newly disabled women in refusing confrontation in managing their family matters reflects the priority given to the Javanese principle of tentrem (harmonious and peaceful living). By practicing nrimo and embracing their disability status they exercised their agency and negotiated their new identity during the early stage of rehabilitation after the earthquake.

\section{Conclusion}

The housing reconstruction programs run by the government and NGOs that utilised traditional principles of gotong-royong enabled local people's speedy recovery in the aftermath of the quake in Yogyakarta. However, the experiences of newly disabled women in the process of disaster recovery reflected different dynamics and consequences. As the most vulnerable group due to their severe injuries, newly disabled women experienced segregation and marginalisation.

The process of marginalisation of the newly disabled women took place from the onset of the housing reconstruction process through the exclusion of their voices in decision making related to the delivery of housing aid, including the matter of property ownership and segregation of post-disaster programs that divided disabled and non-disabled survivors in their daily interactions. Further, the 'accessible house' design in fact disempowered new wheelchair users in interacting with their kampong neighbours and was at odds with the Javanese concept of the ideal home. For example, the narrow living room and tiny kitchen precluded 
the ideal social function of hosting women to help prepare foods (rewang) for any ritual event held by the homeowner. In Javanese society, the kitchen represents a female space because women can freely engage in domestic activities without male intervention. It is also a place to connect with neighbours through its back door (Ju et al., 2018; Newberry, 2006).

The accessibility programs and other programs specifically for the disabled people resulted in prolonged segregation between the disabled and non-disabled people in the village, including within their families. The process of domestication of newly disabled women, both during and after the process of housing reconstruction, contributed to feelings of loneliness and inferiority as disabled women. However, behind their marginalisation and categorisation as a distinct group, these women tackled obstacles in their life by utilising their identity as newly disabled people and mothers to seek aid. They also re-interpreted the meaning of 'home'.

The stereotype-constructed by NGOs and family groups - of the newly disabled women as passive and needing help in the processes of housing reconstruction and rebuilding the household generated different reactions from newly disabled women themselves. All of the women in this study understood that their physical condition could not be changed and that they were unable to control others' responses to their disability condition. Rather than responding with anger to the situation and limiting their choices and opportunity, they followed the flow of their life by adjusting to their family's decision making. Contesting a family decision that was not in their own best interests was not the way to solve the problem. Instead, they exercised their agency by accepting (nrimo) and developing a sense of gratefulness towards the many hands that have helped them to rebuild their new life. Indeed, when something hampered their interests, they thought of strategic and creative ways to realise their ideas.

In the making of domesticity during the process of adjustment to the new house and in the husband and wife's relationship post-earthquake, the newly disabled women were able to maintain their power in the family. They proved that they were still capable of managing the household and earning income for the family through utilising their assets, taking advantage of their networks and maintaining good relationships with their children and siblings. Even though not all the women had the same experience of big support from the family but it showed that the more capital and support a woman had, the smoother her adaptation to the change and bargaining position in the household.

\section{References}

Agamben, G. (1998). Homo Sacer: Sovereign Power and Bare Life (trans: D. Heller Roazen). Redwood City, CA: Stanford University Press.

Brasset, J., and Vaughan-Williams, N. (2012). Crisis is Governance: Sub-prime, The Traumatic Event, and Bare Life. Global Society, 26(1), 19-42.

Drury, J., Brown, R., Gonzalez, R., and Miranda, D. (2016). Emergent Social Identity and Observing Social Support Predict Social Support Provided by Survivors in A Disaster: Solidarity in The 2010 Chile Earthquake. European Journal of Social Psychology, 46(2), 209-223.

Easthope, H. (2004). A Place Called Home. Housing, Theory and Society, 21(3), 128-138.

Enarson, E. (1998). Through Women's Eyes: A Gendered Research Agenda for Disaster Social Science. Disasters, 22(2), 157-173.

Enarson, E. (1999). Women and Housing Issues in Two US Disasters: Case Studies from Hurricane Andrew and the Red River Valley Flood. International Journal of Mass Emergencies and Disasters, 17(1), 39-63.

Fassin, D. (2007). Humanitarianism as a Politics of Life. Public Culture, 19(3), 499-520.

Fassin, D. (2013). The Predicament of Humanitarianism. Qui Parle: Critical Humanities and Social Sciences, 22(1), 33-48.

Geertz, H. (1961). The Javanese Family A Study of Kinship and Socialization. New York: Free Press of Glencoe.

Ghai, A. (2002). Disabled Women: An Excluded Agenda of Indian Feminism. Hypatia, 17(3), 49-66.

Gill, M., and Schlund-Vials, C. J. (2016). Introduction: Protesting "The Hardest Hit." In M. Gill and C. J. Schlund-Vials (Eds.), Disabili- 
ty, Human Rights and The Limits of Humanitarianism (pp. 1-14). Surrey: Ashgate Publishing Limited.

International Organization for Migration Yogyakarta. (2007). New Special Housing, Livelihood Projects Mark Yogya Earthquake Anniversary. Retrieved December 11, 2017, from https://www.iom.int/news/new-special-housing-livelihood-projects-mark-yogya-earthquake-anniversary

Jauhola, M. (2010). "When House Becomes Home"-Reading Normativity in Gender Equality Advocacy in Post-tsunami Aceh, Indonesia. Gender, Technology and Development, 14(2), 173-195.

Jauhola, M. (2015). Scraps of Home: Banda Acehnese Life Narratives Contesting the Reconstruction Discourse of a Post-Tsunami City that is "Built Back Better." Asian Journal of Social Science, 43(6), 738-759.

Jouili, J. S. (2007). Being A Pious French Muslim Woman. Isim Review, 19(2).

Ju, S. R., Do, Y. K., and Santosa, R. B. (2018). Dualism in The Javanese House and Transformation with Focus on The Houses of Kotagede, Yogyakarta. Journal of Asian Architecture and Building Engineering, 17(1), 71-78.

Kamani-Fard, A., Ahmad, M. H., and Ossen, D. R. (2012). The Sense of Place in The New Homes of Post-Bam Earthquake Reconstruction. International Journal of Disaster Resilience in the Built Environment.

Kim, E. (2016). The Specter of Vulnerability and Disabled Bodies in Protest. In M. Gill and C. J. Schlund-Vials (Eds.), Disability, Human Rights and The Limits of Humanitarianism (pp. 137-154). Surrey: Ashgate Publishing Limited.

Kresnomukti, Y., and Deutsche Gesellschaft für Technische Zusammenarbeit. (2009). Grubyuk rembuk untuk mbangun: participatory development a la CAP: experiences compiled during the post-earthquake reconstruction in Yogyakarta and Klaten (Central Java). Bonn: Deutsche Gesselschaft fur Technische Zusammenarbeit.

Mahmood, S. (2011). Politics of Piety: The Islamic Revival and The Feminist Subject. New Jersey: Princeton University Press.

Marcillia, S. R., and Ohno, R. (2012). Learning from Resident's Adjustments in Self-built and Donated Post Disaster Housing after Java Earthquake 2006. Procedia-Social and
Behavioral Sciences, 36, 61-69.

Meekosha, H. (2011). Decolonising Disability: Thinking and Acting Globally. Disability and Society, 26(6), 667-682.

Meekosha, H., and Soldatic, K. (2011). Human Rights and The Global South: The Case of Disability. Third World Quarterly, 32(8), 1383-1397.

Mulder, N. (1983). Abangan Javanese Religious Thought and Practice. Bijdragen Tot de Taal, Land-En Volkenkunde, 2/3 Afl, 260-267.

Newberry, J. C. (2006). Back Door Java: State Formation and The Domestic in Working Class Java. Toronto: University of Toronto Press.

Pathranarakul, P., and Moe, T. L. (2006). An Integrated Approach to Natural Disaster Management: Public Project Management and Its Critical Success Factors. Disaster Prevention and Management, 15(3), 396-413.

Persson, H., Åhman, H., Yngling, A. A., and Gulliksen, J. (2015). Universal Design, Inclusive Design, Accessible Design, Design for All: Different Concepts-One Goal? On The Concept of Accessibility-Historical, Methodological and Philosophical Aspects. Universal Access in the Information Society, 14(4), 505-526.

Phillips, K. (2009). Interventions, Interceptions, Separations: Australia's Biopolitical War at The Borders and The Gendering of Bare Life. Social Identities, 15(1), 131-147.

Pribadi, K. S., Kusumastuti, D., Sagala, S. A., and Wimbardana, R. (2014). Post-disaster Housing Reconstruction in Indonesia: Review and Lessons from Aceh, Yogyakarta, West Java and West Sumatera Earthquakes. In Disaster Recovery (pp. 197-223). Tokyo: Springer.

Qureshi, K. (2013). Sabar: Body Politics among Midle-aged Migrant Pakistani Women. Journal of The Royal Anthropological Institute, 19(1), 120-137.

Rini, J. A., Triyadi, S., and Yuwono, T. (2016). Perubahan Perilaku Membangun Rumah Pasca Gempa 2006 di Yogyakarta-Studi Kasus Pengembangan Rumah Bantuan JRF di Kabupaten Bantul. NALARs, 15(1), 45-54.

Samuels, A. (2012). After The Tsunami: The Remaking of Everyday Life in Banda Aceh, Indonesia (University of Leiden). Retrieved from https://openaccess.leidenuniv.nl/handle/1887/20190

Tumer, J. (1981). The Experimental Social Psychology of Intergroup Behavior. In C. Tumer 
and H. Giles (Eds.), Intergroup Behaviour (pp. 66-101). Oxford: Blackwell.

United Nations International Strategy for Disaster Reduction. (2009). UNISDR Terminology on Disaster Risk Reduction. Retrieved February 3, 2018, from UNISDR website: https://www.unisdr.org/files/7817_UNISDRTerminologyEnglish.pdf

Young, I. M. (2005). House and Home: Feminist Variations on A Theme. In Motherhood and Space (pp. 115-147). New York: Palgrave Macmillan. 